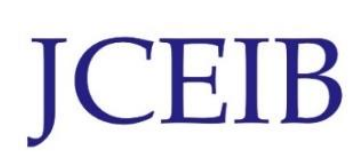

Journal Chemical Engineering and Industrial Biotechnology (JCEIB)

Open Access

Volume 3 pp. 26-36; March 2018

(C) Universiti Malaysia Pahang Publisher

DOI: https://doi.org/10.15282/JCEIB-V3-05.28/3/2018/3.3

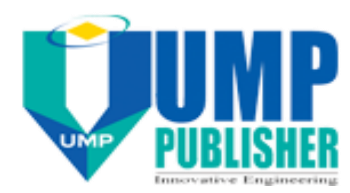

\title{
INFLUENCED FACTORS IN THE DELIGNIFICATION PROCESS OF RED MERANTI WOOD SAWDUST
}

\author{
S.N. Abdul Rahman ${ }^{\text {a }}$, Mimi Sakinah Abdul Munaim, ${ }^{\text {a, }}$ \\ ${ }^{a}$ Faculty of Engineering Technology, Universiti Malaysia Pahang, \\ 26300 Kuantan, Pahang, Malaysia \\ * Corresponding author: E-mail: mimi@ump.edu.my \\ Tel.: +609-5493191 Fax.: +609-5492689
}

\begin{abstract}
Lignocellulosic biomass are plants that include forestry residue and agricultural residues that are mainly composed of cellulose, hemicelluloses and lignin. Red Meranti wood sawdust (RMWS) are one of lignocellulosic biomass that rich-cellulose content. To obtain cellulose, the pretreatments are needed to extract it from outer layer of lignin and hemicellulose by using the acid-chlorite delignification procedure aided with design of experimental from Design Expert 7.1 software. Four factors were selected in design of experiment using two level with half fraction factorial analysis were came out with total of 8 runs. The factors contributed were ratio acetic acid (AC) to RMWS (0.45 and 0.6), ratio sodium chlorite to RMWS (0.6 and 1.64), reaction time (4hr and $6 \mathrm{hr}$ ) and temperature $\left(55^{\circ} \mathrm{C}\right.$ and $\left.75^{\circ} \mathrm{C}\right)$. The results obtained were showed that the design model was substantial resulting with a coefficient of determination value of 0.9963 . Two factors that generated the highest to the process were ratio SC to RMWS (B) and temperature (D). The percentage error between the actual and predicted value for lignin removal at $0.79 \%$ and $4.92 \%$, which found to be less than $5 \%$, and thus, the model was successfully validated.
\end{abstract}

Keywords: Red Meranti wood sawdust, delignification, design of experiment., factorial analysis

\subsection{INTRODUCTION}

Lignocellulosic biomasses are typically the fibrous or nonedible plant materials, comprising about $50 \%$ of the world biomass resources (Fernandes et al., 2015). One of the example of lignocellulosic biomasses is Red Meranti wood sawdust (RMWS), which is the residues from logging and sawmill activities. The lignocellulosic components of RMWS are embedded in ultimate structure that compose of three main components; lignin, hemicellulose and cellulose (Hanley et al., 1997; Yu et al., 2005). Lignin is the plant cell wall adhesive used for structural protection. Apart from that, lignin also tends to inhibit any damage or reaction occurs to the internal parts (hemicellulose and cellulose). This recalcitrance will affect potential applications of cellulose in the further processing (Studer et al., 2011).

Delignification process is to remove, dislocate and/or change the lignin structure so that cellulose is exposed for next reaction process. This process is important because it ensures effective characterizations and applications of cellulose. According to Ishizawa et al. 
(2009), knowing the structure and morphology of the lignocellulosic materials also would help the effort to reduce the biomass recalcitrance (Ishizawa et al., 2009). High percentage of lignin removal during the pretreatment is a pre-requisite for successful downstream process.

The specific delignification methods have been studied including ionic-liquid extraction (Lee et al., 2009), oxygen delignification (Koo et al., 2011), ozone delignification (García-Cubero et al., 2009), and acidified sodium chlorite or paracetic acid delignification (Hubbell \& Ragauskas, 2010; Kumar et al., 2013). Others pretreatments showed to be significant in delignify the lignin such as physical pretreatment, ball milling combined with steam explosion (Asada et al ., 2011), chemical pretreatment, for example organosolv pretreatment, alkali or lime pretreatment (Romaní et al., 2011; Li \& Kim, 2011; Fuentes et al., 2010) and that usually be the subsequence stage for further processing to recover the cellulose.

Chemical treatment that utilize acidified sodium chlorite delignification, was formerly known as the Wise method (Wise et al., 1946) could be used to pretreat the RMWS. This method is usually operated at $60-70^{\circ} \mathrm{C}$ for $4-8$ hours with one or two hour intervals of reagents loading at 0.3-0.6 g sodium chlorite/g dry biomass and 0.1-0.6ml acetic acid/g dry biomass (Ahlgren \& Goring, 1971; Hubbell \& Ragauskas, 2010; Timell, 1961). For a procedure based on acidified sodium chlorite is commonly used as a preliminary step for delignification process to produce holocellulose, generally for softwoods and verified with higher selective without affecting the conditions (Jungnikl et al., 2008; Loader et al., 1997; Siqueira et al., 2013) In addition, the extensive delignification using oxidizing agent would change disturb the cellulose degree of polymerization (P. Kumar et al., 2009).

The delignification of RMWS acidified sodium chlorite is yet to be studied by previous researchers. Hence, the objective of this study intended to fill this gap with the use of two-level fractional factorial analysis. Identified factors that potentially could affect the percentage of lignin removal in Red Meranti wood sawdust (RMWS) using acidified sodium chlorite delignification were the ratio of sodium chlorite to RMWS, the ratio of acetic acid to RMWS, temperature and reaction time. In a later stage, optimization could be performed to consider interactions among the studied factors.

\subsection{METHODOLOGY}

In this study, RMWS was obtained from Kilang Papan Sg Charu Sdn. Bhd, located at Sungai Lembing, Kuantan, Pahang. Figure 1 shows this raw RMWS and Table 1 tabulates morphological composition of RMWS. In considering those factors affecting the delignification process, acid-insoluble lignin analysis was the method used to determine the lignin content of raw RMWS and treated RMWS.

\subsection{Raw Materials Processing}

Raw RMWS was screened to remove the oversized particles and dross and followed by sun dried. The dried RMWS was then pass through a $0.5 \mathrm{~mm}$ manual siever to select a particle size $<0.5 \mathrm{~mm}$ and stored in polypropylene sealed bags at the ambient temperature and pressure. Portion of RMWS was then oven dried at $105^{\circ} \mathrm{C}$ for 12 hours, and cooled in room temperature. 


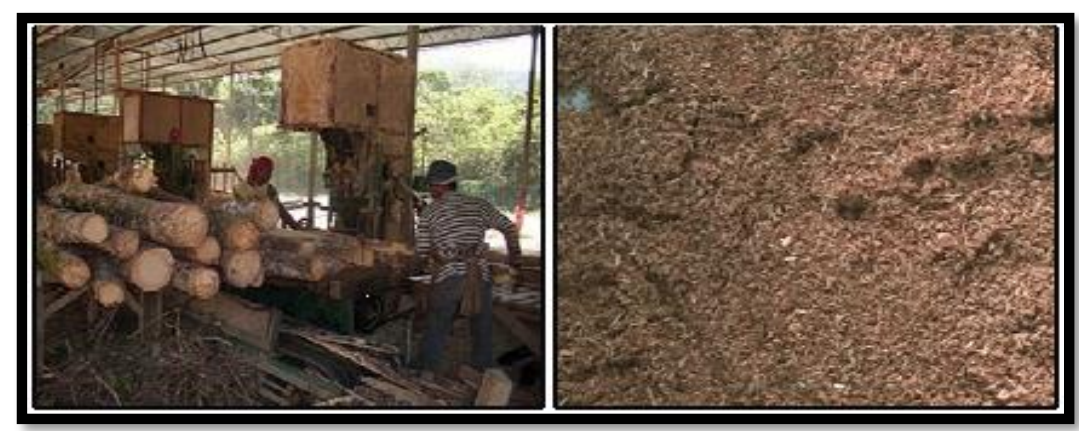

Figure 1: Raw Red Meranti Wood Sawdust (RMWS)

Table 1: Morphological composition of Red Meranti wood sawdust (Adapted from Siti Sabrina and Mimi Sakinah, 2017)

\begin{tabular}{|c|c|}
\hline Composition & \% Total dry weight $\mathbf{w}^{\mathbf{a}}(\mathbf{w} / \mathbf{w})$ SD \\
\hline Cellulose & $47.72 \pm 0.05$ \\
\hline Hemicellulose & $24.88 \pm 0.57$ \\
\hline Lignin & $27.75 \pm 2.02$ \\
\hline
\end{tabular}

${ }^{a}$ All the data are based on the average replicated of three times samples of initial oven dried weight sample

\subsection{Experimental Setup For Sodium Chlorite-Acetic Acid (SC/AC)}

Experimental was set up for acidified chlorite delignification. Four identified factors; i) the ratio of acetic acid to RMWS (A), ii) the ratio of sodium chlorite to RMWS (B), iii) reaction time $(C)$, and iv) temperature (D) were screened during the delignification process. In duplicates, $20 \mathrm{grams}$ of dry biomass was measured into $500 \mathrm{ml}$ beaker, and then $320 \mathrm{ml}$ of deionized (DI) water was added subsequently loaded with two different ratio SC to RMWS and two different ratio AC to RMWS. The sealed oil bath (Martin Walter's ultrasonic) was used to control the temperature (A) at $55^{\circ} C$ and $75^{\circ} C$ using the constant speed 350rpm and fresh charges of sodium chlorite and acetic acid were added to the reaction for every 80 minutes or 2 hours. The time reaction (B) was controlled by removing the samples from oil bath at specific time, 4 hour and 6 hours. The total amount of acetic acid and sodium chlorite added to the sample at respective ratio of 0.45 and $0.6 ; 0.76$ and 1.64. After completion of reaction, the solution was vacuum filtered on a glass fiber filter, and the solids were continually washed until the $\mathrm{pH}$ of filtrate was almost to 7 using DI water. Filtrate were cautiously scraped off the glass fiber filter and the filtrate were dried in oven at $45^{\circ} \mathrm{C}$ until the weight remaining constant with moisture content is less than $5 \%$. For mass balance, the dry weight of delignified solids in triplicates were recorded. The amount of biomass yield from delignification process was calculated as:

$$
\text { Biomass recovery }\left(\text { Yield }, Y_{B}\right)=100 \frac{\text { Amount of dry biomass recovered after reaction }(g)}{\text { Initial amount of dry solid }(g)}
$$

\subsection{Two Level Fractional Factorial Analysis}

Two-level factorial analysis at half fraction was applied to this research with assist of Design Expert 7.1 software were resulting 8 runs in total and each run was triplicate. Table 2 shows condition and values of the high level and low level for each factor. The range of each factor was based on previous researches (Ahlgren \& Goring, 1971; Hubbell \& Ragauskas, 2010; Kumar, K et al., 2013, Wise et al,. 1946). 
Table 2: Process screening for each factor

\begin{tabular}{|l|c|c|c|c|}
\hline Factor & Symbol & $\begin{array}{c}\text { Low level } \\
\mathbf{a = - 1}\end{array}$ & $\begin{array}{c}\text { High Level } \\
\mathbf{a = + 1}\end{array}$ & Unit \\
\hline $\begin{array}{l}\text { Ratio of acetic acid to } \\
\text { RMWS }\end{array}$ & $\mathrm{A}$ & 0.45 & 0.6 & $\begin{array}{c}\text { No } \\
\text { unit }\end{array}$ \\
\hline $\begin{array}{l}\text { Ratio of sodium } \\
\text { chlorite to RMWS }\end{array}$ & $\mathrm{B}$ & 0.76 & 1.64 & $\begin{array}{c}\text { No } \\
\text { unit }\end{array}$ \\
\hline Temperature & $\mathrm{C}$ & 55 & 75 & ${ }^{\circ} \mathrm{C}$ \\
\hline Reaction time & $\mathrm{D}$ & 4 & 6 & hour \\
\hline
\end{tabular}

\subsection{Acid Insoluble Lignin Analysis}

The acid insoluble lignin analysis was performed regarding to the National Renewable Energy Laboratory (NREL) using method (Sluiter et al., 2011). For estimation, firstly, the method was created to delignify the process using acidified chlorite treatment from RMWS. The analysis was carried out using water bath and autoclave. Each sample of $300 \mathrm{mg}$ was added with $3 \mathrm{ml}$ of $72 \%$ sulfuric acid and incubated in water bath at $30 \circ \mathrm{C}$ for 1 hour. After that, the samples were diluted to a $4 \%$ concentration before placed in autoclave safe rack for 1 hour at $121^{\circ} \mathrm{C}$. The sample was filtered in filtering flask. The acid insoluble residue was dried in oven at $10^{\circ} \mathrm{C}$ until constant weight was achieved. All the data for initial oven dried weight sample are based on the average triplicates.

The percentage of acid-insoluble lignin (AIL) removal is determined as follows:

$$
\text { Acid insoluble lignin }(A I L) \text { removal, } \%=\frac{A-B}{W} \times 100
$$

where A is weight of untreated lignin (g), B is weight of treated lignin $(\mathrm{g})$ and $\mathrm{W}$ is the oven-dry weight of test specimen $(\mathrm{g})$.

\subsection{RESULT AND DISCUSSION}

The previous studies related with the delignification process on lignocellulosic biomass discovered that various reaction parameters can be influences the process (Hubbell \& Ragauskas, 2010; Siqueira et al., 2013). For this chemical treatment of delignification, sodium chlorite acted as strong oxidizing agent that generates chlorine dioxide in situ to bleach and to delignify the RMWS.

\subsection{Process Screening for Sodium Chlorite-Acetic Acid Treatment (SC/AA)}

The two-level fractional factorial design by design expert software was used for screening process of four studied parameters which include of the ratio of acetic acid to RMWS (A), the ratio of sodium chlorite to RMWS (B), reaction time (C), and temperature (D) were done to identify which independent factors give the most significant contribution to the percentage of delignification of Red Meranti Wood Sawdust (RMWS) as the response variable (Y) using acidified sodium chlorite treatment. This factorial design also resulted the interaction and optimize the range between each factor. Experimental design running sequences and the responses obtained (Y) are shown in Table 3. 
Table 3: Design of experiment for process screening via $2^{4-1}$ fractional factorial design and the responses obtained with biomass yield obtained

\begin{tabular}{|c|c|c|c|c|c|c|}
\hline \multirow[t]{2}{*}{ Run } & \multicolumn{4}{|c|}{ Factor } & \multirow{2}{*}{$\begin{array}{c}\text { Response, Y } \\
\text { Lignin Removal (\%) }\end{array}$} & \multirow{2}{*}{$\begin{array}{c}\text { Biomass } \\
\text { Yield }^{x}(\%)\end{array}$} \\
\hline & A & B & C & D & & \\
\hline 1 & -1 & 1 & 1 & 1 & 90.56 & 74.87 \\
\hline 2 & -1 & -1 & -1 & 1 & 46.67 & 87.05 \\
\hline 3 & 1 & 1 & -1 & 1 & 93.87 & 73.95 \\
\hline 4 & 1 & -1 & -1 & -1 & 46.67 & 87.05 \\
\hline 5 & -1 & -1 & 1 & -1 & 49.44 & 79.86 \\
\hline 6 & -1 & 1 & -1 & -1 & 57.77 & 83.97 \\
\hline 7 & 1 & 1 & 1 & -1 & 60.56 & 83.20 \\
\hline 8 & 1 & -1 & 1 & 1 & 47.78 & 89.04 \\
\hline
\end{tabular}

Regarding to Kumar et al, supported Wise et al, with the addition of acetic acid to the aqueous solution of chlorite for every 2 hour, it liberated chlorine dioxide which in turn reacts with RMWS or wood fibres to produce chlorite holocellulose for up to $6-8$ hours at $70^{\circ} \mathrm{C}$ (Kumar et al., 2013a; Wise et al., 1946).for this study, the RMWS was delignified for up to 6 hours between temperature of $55^{\circ} \mathrm{C}$ to $75^{\circ} \mathrm{C}$ with two different dosage of sodium chlorite and acetic acid. As the result, the biomass yields that produced holocellulose is shown in Table 3. The range of biomass yields were between $74 \%$ to $89 \%$ with the highest percentage on Run 8 with $89.04 \%$ and lowest on Run 3, with $73.95 \%$. During the process, chemical reactions have caused the lignin to become soluble and eventually degraded. The degree of bleaching and delignification reactions were dictated by the operating temperature and the amount of chemicals that were added. This show that that have the liquid solid ratio range (ratio of chemical dosage to sawdust), temperature and reaction time affect the delignification on RMWS.

\subsection{Main and Interaction Effect Analysis}

Each of the factor attributing to the deliginication reaction process from the two level factorial analysis, was examined using the software. The contribution percentage for each identified factor to the delignification process is shown in Table 4 . The ratio of sodium chlorite to RMWS (B) depicted as the most significant factor with value of $58.71 \%$ followed by $\mathrm{AC}$ (between two interaction $\mathrm{AC}$ and reaction time) and temperatue (D) at value of $19.37 \%$. The ratio of acetic acid to RMWS (A) and temperature (D) showed low values of contribution percentage at 0.092 and 0.053 , respectively.

Table 4: Percentage Contribution of each factor

\begin{tabular}{|c|c|}
\hline Factor & $\begin{array}{c}\text { Percentage Contribution } \\
\text { Response 1 }\end{array}$ \\
\hline A & 0.092 \\
\hline B & 58.71 \\
\hline C & 0.053 \\
\hline D & 19.37 \\
\hline AC & 21.41 \\
\hline
\end{tabular}




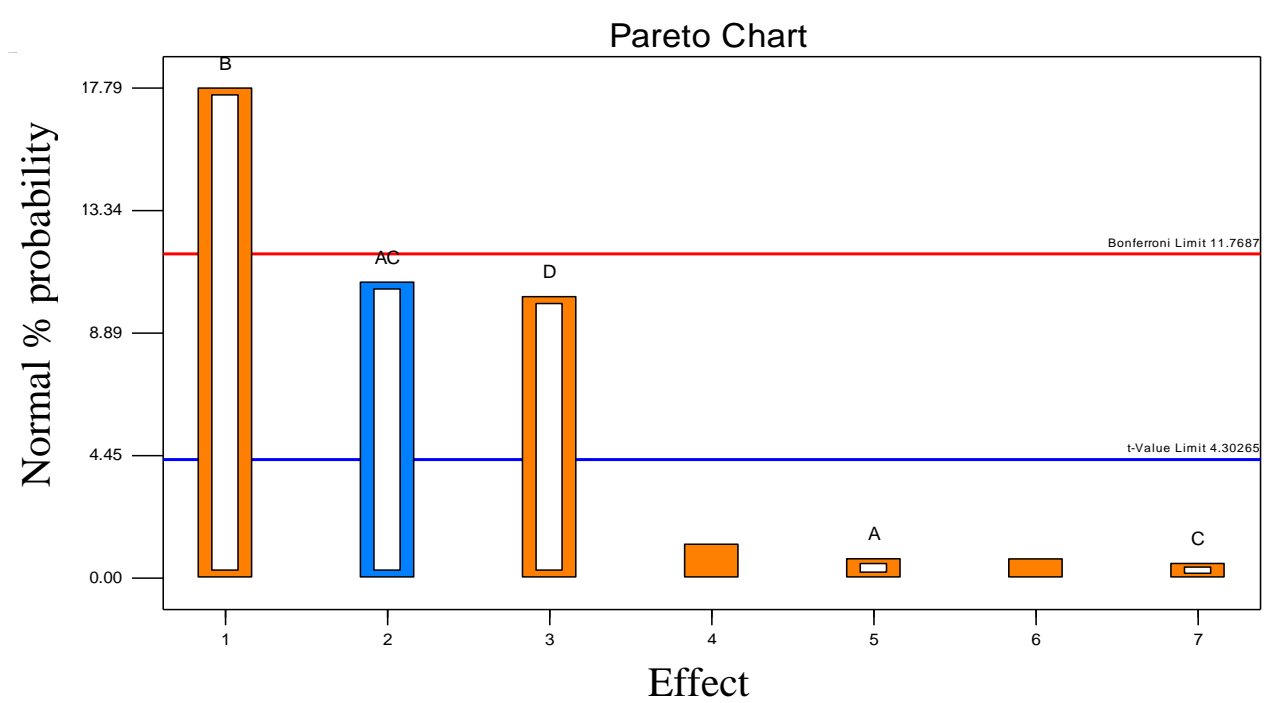

Figure 3: Pareto Charts for each factors with their value effect for response

The main effect also can be represented by the pareto chart as in Figure 3. According to that, delignify of RMWS was affected by reagent loadings of sodium chlorite, reaction time and the temperature. Furthermore, Table 3 reveals that the percentage of lignin removal at Run 3 was $93.87 \%$ at ratio AC to RMWS (A) of 0.6, ratio SC to RMWS (B) of 1.64 , reaction time (C) of 6 hours and temperature (D) of $75^{\circ} \mathrm{C}$. This result was found to be consistent with studies done by R. Kumar et al., 2013a who reported that exceeded $90 \%$ of the lignin successfully was detached after $6 \mathrm{hrs}$ of reaction time using similar $\mathrm{SC} / \mathrm{AC}$ reagents but have utilized different raw material, which were poplar, corn stover, switchgrass, and pine sawdust.. They said these reagants dosage (1.8 of ratio to dry biomass for both chemicals) and a 6 hours of reaction time were optimum to remove utmost of the lignin content (Kumar, et al., 2013). This statement is well supported by (Siqueira et al., 2013) mentioned that the effects of reaction time up to 4 hours for acidified sodium chlorite delignification on sugarcane baggase resulting only $76.2 \%$ of lignin removal. They have discovered that the optimum reaction time was on first two hours. This statements can be explained by following two justifications, which are; it happened at the beginning of reaction time, whereas more lignins are available to degrade and solubilize; and according to Siqueira et al, firstly, the chemical reagents went through the lumen and cell wall, then, degrading the accesible lignin in secondary cell wall and leaving the left lignin in the middle lamella, known more recalcitrant than others (Siqueira, et al,., 2011).

\subsection{Statistical Modeling and ANOVA}

Estimation of the experimental error variances allowed significance of the coefficient to be evaluated. Therefore, the analysis of variace (ANOVA) was carried out and tabulated in Table 5. The components in this study were screened at the confidence level of $95 \%$ on the basis of their effect. The regression model was found to be significant $(P<0.05)$, indicating the change in observed response was due to the change of examined factors. In this study, statistical model analysis was performed using Fisher's statistical test ( $F$ Value). As mentioned by Panda et al., 1999, F Value is the ratio of regression mean square to real error mean square. As can be seen in Table 5, the F value corresponding to lignin removal (\%) are 107.39 . There is only a $0.93 \%$ chance that a "Model F Value" this large could occur due to noise. 
As can be inferred from Table 5, the $P$ Value implies that the ratio of sodium chlorite to RMWS (B), the two level interactions of acetic acid and reaction time (AC) and also temperature (D) were the significant factors that affected the lignin removal (\%). However, the other factors i.e the ratio AC to RMWS (A), reaction time (C) and two level interactions of $\mathrm{AB}$ and $\mathrm{AD}$ gave insignificant or may still have very minor effects to the lignin removal process. These results corresponds with the discussion in 3.2, main and interaction effect analysis.

Table 5: ANOVA table and summary of fit for final lignin content (\%)

\begin{tabular}{|l|c|c|c|c|c|}
\hline Source & $\begin{array}{c}\text { Sum of } \\
\text { Squares }\end{array}$ & $\begin{array}{c}\text { Mean } \\
\text { Square }\end{array}$ & $\boldsymbol{F}$ Value & $\begin{array}{c}\boldsymbol{P} \text {-value } \\
\text { Prob > F }\end{array}$ & \\
\hline Model & 2670.47 & 534.09 & 107.39 & 0.0093 & significant \\
\hline A & 2.46 & 2.46 & 0.50 & 0.5544 & \\
\hline B & 1573.60 & 1573.60 & 316.39 & 0.0031 & \\
\hline C & 1.41 & 1.41 & 0.28 & 0.6475 & \\
\hline D & 519.06 & 519.06 & 104.36 & 0.0094 & \\
\hline AC & 573.93 & 573.93 & 115.39 & 0.0086 & \\
\hline Residual & 9.95 & 4.97 & & & \\
\hline Cor Total & 2680.42 & & & & \\
\hline
\end{tabular}

The accuracy of the model was designated by the value of coefficient $\left(R^{2}\right)$ and correlation coefficient (R). According to the Table 6, the determination coefficient $\left(R^{2}\right)$ was calculated to be 0.9963 , representing that the model has able to understand that $99.63 \%$ of the data unpredictability and only a $0.37 \%$ chance the data not fit. In addition, the predicted $R^{2}$ was practical with the adjusted $\left(R^{2}\right) R^{2}$, since it depicted less than 0.2 different between predicted and adjusted and adjusted $\left(R^{2}\right) R^{2}$. In overall, adequate precision was the comparison between the ranges of the predicted values at the design point to the average prediction error. Table 6 shows the acceptable accuracy greater than 4 , which indicated adequate model discernment.

Table 6: Statistical analysis from ANOVA

\begin{tabular}{|l|c|}
\hline \multirow{2}{*}{ Description } & \multicolumn{1}{c|}{ Response } \\
\cline { 2 - 2 } Std. Dev. & Lignin Removal (\%) \\
\hline Mean & 2.23 \\
\hline R-Squared & 61.66 \\
\hline Adj R-Squared & 0.9963 \\
\hline Pred R-Squared & 0.9870 \\
\hline Adeq Precision & 0.9406 \\
\hline
\end{tabular}

Table 7 meanwhile shows the coefficient regression where the value of $\alpha_{0}$ was greater than others value. The present design plateau was proved since the other coefficient of factors were lower than the intercept. This plateau presented that the design had a maximum point which considerably to be the optimum point and likely for the optimization process. 
Table 7: Coefficient regression for factor screening process

\begin{tabular}{|l|c|}
\hline \multirow{2}{*}{ Factor } & $\begin{array}{c}\text { Coefficient Estimate } \\
\text { Response }\end{array}$ \\
\hline $\boldsymbol{\alpha}_{\mathbf{0}}$ & 61.67 \\
\hline $\boldsymbol{\alpha}_{\mathbf{1}}$ & 0.55 \\
\hline $\boldsymbol{\alpha}_{\mathbf{2}}$ & 14.03 \\
\hline $\boldsymbol{\alpha}_{\mathbf{3}}$ & 0.42 \\
\hline $\boldsymbol{\alpha}_{\mathbf{4}}$ & 8.05 \\
\hline $\boldsymbol{\alpha}_{\mathbf{1}} \boldsymbol{\alpha}_{\mathbf{3}}$ & -8.47 \\
\hline
\end{tabular}

With the values from Table 7, mathematical model that described the contributed factors of deliginification of RMWS could be expressed by the equation 1 and 2 below;

$$
\begin{aligned}
& \text { i.Percentage of lignin removal, } y_{1} \text { (Model) } \\
& \qquad y_{1}=61.67+0.55 \alpha_{1}+14.03 \alpha_{2}+0.42 \alpha_{3}+8.05 \alpha_{4}-8.47 \alpha_{1} \alpha_{3} \quad \text { (Equation 1) } \\
& \text { ii.Percentage of lignin removal, } Y_{1} \text { (Actual), } \\
& \quad Y_{1}=-331.35+572.07 A+31.88 B+59.71 C+0.81 D-111.93 A C \quad \text { (Equation 2) }
\end{aligned}
$$

The screening results demostrate that the amount of sodium chlorite (B) to reaction mixtures had the strongest simulation effects on delignification of RMWS according to the coefficient of these regreesion models (Equation 1 and 2) as can be inferred from table 4 and table 5, as well as figure 3.

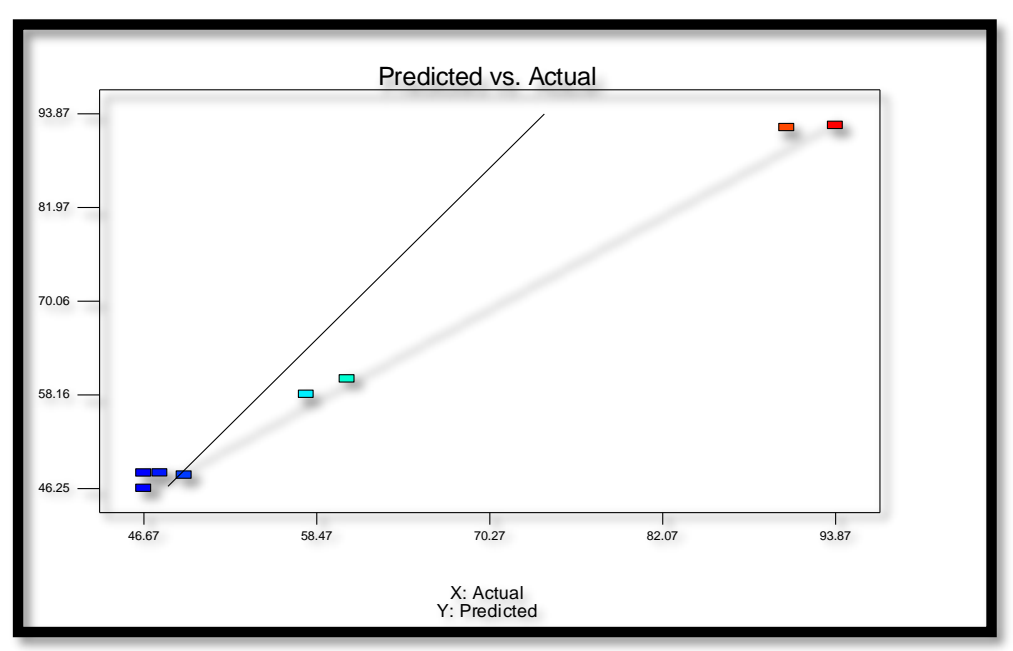

Figure 4: The graph of predicted vs actual of lignin removal (\%)

Refer to figure 4, the straight line showing the point where the predicted value is equivalent to the actual value. All of 8 runs had the little margin of different between predicted and actual value that contributed to the coefficient od determination value resulted in the ANOVA as table 5. From 8 runs, Run 1 had the largest margin as the 
predicted value was $90.56 \%$ and and the actual one was $92.08 \%$, while Run 6 and Run 7 had smallest margin with $0.42 \%$ different.

\subsection{Data Validation Process}

The validation runs were carried out by performing experiment of two points from screening table and solution table. The value of the theoretical percentage and the experiment percentage were compared and their errors were calculated. The result attained were organised in Table 8.

Table 8: The percentage of lignin removal value obtained from validation run in comparison with the theoretical value from Design Expert 7.1

\begin{tabular}{|c|c|c|c|}
\hline Point & Actual Value (\%) & Theoretical value (\%) & Error (\%) \\
\hline A & 93.128 & 93.87 & 0.79 \\
\hline B & 97.82 & 92.35 & 4.92 \\
\hline
\end{tabular}

From this table, the percentage error of point $\mathrm{A}$ and point $\mathrm{B}$ were $0.79 \%$ and $4.92 \%$, respectively. Point A was at the $3^{\text {rd }}$ run in the screening experimental table, while point $\mathrm{B}$ was the suggested point for highest percentage of lignin removal. The factors condition for both points was ratio AC to RMWs of 0.6, ratio SC to RMWS of 1.64, reaction time of $6 \mathrm{hrs}$ and temperature of $75^{\circ} \mathrm{C}$. Each run was carried in replication for three times. The validation process was achievable with the percentage error less than $5 \%$, proving that the process screening was proved. The factorial analysis demonstrated that the recovery of cellulose from RMWS were influenced by the amount input of sodium chlorite to chemical reagents in mixture and reaction time of the whole process. Thus, the effect of these independent variables will be further analysed by Central Composite Design (CCD) to optimise the highest percentage of lignin removal from RMWS.

\subsection{CONCLUSION}

RMWS biomass contain less than $30 \%$ of lignin, which are successfully achieved up to $90 \%$ of lignin removal. Factorial analysis has able to determine the contributed factors that gave the most significant effect to percentage of lignin removal in acidified sodium chlorite delignification process from RMWS. Out of 4 identified factors, two of them which were the ratio of sodium chlorite to RMWS (B) and temperature (D) have shown considerable effects in the delignification process, with values of $58.71 \%$ and 19.37 , respectively. In addition, the two levels interaction factor of AC has affected the delignification process with $21.41 \%$. The data validation also showed that only less than $4.92 \%$ percentage error occurred, means that the experiment are repeatable. The precision ANOVA of model is indicated by the determination coefficient $(R 2)$ is at 0.9963 which verified that the model is significant to the experimental design with the validation process was achievable with the percentage error less than $5 \%$.

\section{ACKNOWLEDGEMENT}

The authors would like to express appreciations to the financial supports received from Universiti Malaysia Pahang's internal research grant, RDU 1703325 to conduct this research. Acknowledgement also is dedicated to the Laboratory Team of the Faculty of Engineering Technology, Universiti Malaysia Pahang. 


\section{REFERENCES}

Ahlgren, P. A., \& Goring, D. A. I. (1971). Removal of Wood Components During Chlorite Delignification of Black Spruce. Canadian Journal of Chemistry, 49(8), 1272-1275. https://doi.org/10.1139/v71-207

Asada, C., Kita, A., Sasaki, C., \& Nakamura, Y. (2011). Ethanol production from disposable aspen chopsticks using delignification pretreatments. Carbohydrate Polymers, 85(1), 196-200. https://doi.org/10.1016/j.carbpol.2011.02.020

Fernandes, M. C., Ferro, M. D., Paulino, A. F. C., Mendes, J. A. S., Gravitis, J., Evtuguin, D. V., \& Xavier, A. M. R. B. (2015). Enzymatic saccharification and bioethanol production from Cynara cardunculus pretreated by steam explosion. Bioresource Technology, 186, 309-315. https://doi.org/10.1016/j.biortech.2015.03.037

Fuentes, L. L. G., Rabelo, S. C., Filho, R. M., \& Costa, A. C. (2011). Kinetics of lime pretreatment of sugarcane bagasse to enhance enzymatic hydrolysis. Applied Biochemistry and Biotechnology, 163(5), 612-625. https://doi.org/10.1007/s12010010-9067-0

García-Cubero, M. T., González-Benito, G., Indacoechea, I., Coca, M., \& Bolado, S. (2009). Effect of ozonolysis pretreatment on enzymatic digestibility of wheat and rye straw. Bioresource Technology, 100(4), 1608-1613. https://doi.org/10.1016/j.biortech.2008.09.012

Hanley, S., Revol, J.-F., Godbout, L., \& Gray, D. (1997). Atomic force microscopy and transmission electron microscopy of cellulose from Micrasterias denticulata; evidence for a chiral helical microfibril twist. Cellulose, 4(3), 209-220. https://doi.org/10.1023/A:1018483722417

Hubbell, C. A., \& Ragauskas, A. J. (2010). Bioresource Technology Effect of acidchlorite delignification on cellulose degree of polymerization. Bioresource Technology, 101(19), 7410-7415. https://doi.org/10.1016/j.biortech.2010.04.029

Ishizawa, C. I., Jeoh, T., Adney, W. S., Himmel, M. E., Johnson, D. K., \& Davis, M. F. (2009). Can delignification decrease cellulose digestibility in acid pretreated corn stover? Cellulose, 16(4), 677-686. https://doi.org/10.1007/s10570-009-9313-1

Jungnikl, K., Paris, O., Fratzl, P., \& Burgert, I. (2008). The implication of chemical extraction treatments on the cell wall nanostructure of softwood. Cellulose, 15(3), 407-418. https://doi.org/10.1007/s10570-007-9181-5

Koo, B. W., Treasure, T. H., Jameel, H., Phillips, R. B., Chang, H. M., \& Park, S. (2011). Reduction of enzyme dosage by oxygen delignification and mechanical refining for enzymatic hydrolysis of green liquor-pretreated hardwood. Applied Biochemistry and Biotechnology, 165(3-4), 832-844. https://doi.org/10.1007/s12010-011-9301-4

Kumar, A. K., \& Sharma, S. (2017). Recent updates on different methods of pretreatment of lignocellulosic feedstocks: a review. Bioresources and Bioprocessing. https://doi.org/10.1186/s40643-017-0137-9

Kumar, P., Barrett, D. M., Delwiche, M. J., Stroeve, P., Kumar, P., Barrett, D. M., ... Stroeve, P. (2009). Methods for Pretreatment of Lignocellulosic Biomass for Efficient Hydrolysis and Biofuel Production Methods for Pretreatment of Lignocellulosic Biomass for Efficient Hydrolysis and Biofuel Production. https://doi.org/10.1021/ie801542g

Kumar, R., Hu, F., Hubbell, C. A., Ragauskas, A. J., \& Wyman, C. E. (2013a). Bioresource Technology Comparison of laboratory delignification methods, their selectivity, and impacts on physiochemical characteristics of cellulosic biomass. Bioresource Technology, 130, 372-381. https://doi.org/10.1016/j.biortech.2012.12.028

Kumar, R., Hu, F., Hubbell, C. A., Ragauskas, A. J., \& Wyman, C. E. (2013b). 
Comparison of laboratory delignification methods, their selectivity, and impacts on physiochemical characteristics of cellulosic biomass. Bioresource Technology, 130, 372-381. https://doi.org/10.1016/j.biortech.2012.12.028

Lee, S. H., Doherty, T. V., Linhardt, R. J., \& Dordick, J. S. (2009). Ionic liquid-mediated selective extraction of lignin from wood leading to enhanced enzymatic cellulose hydrolysis. Biotechnology and Bioengineering, 102(5), 1368-1376. https://doi.org/10.1002/bit.22179

Li, X., \& Kim, T. H. (2011). Low-liquid pretreatment of corn stover with aqueous ammonia. Bioresource Technology, 102(7), 4779-4786. https://doi.org/10.1016/j.biortech.2011.01.008

Loader, N. J., Robertson, I., Barker, A. C., Switsur, V. R., \& Waterhouse, J. S. (1997). An improved technique for the batch processing of small wholewood samples to $\alpha$ cellulose. Chemical Geology, 136(3-4), 313-317. https://doi.org/10.1016/S00092541(96)00133-7

Panda, T., Naidu, G. S. N., \& Sinha, J. (1999). Multiresponse analysis of microbiological parameters affecting the production of pectolytic enzymes by Aspergillus niger: A statistical view. Process Biochemistry, 35(1-2), 187-195. https://doi.org/10.1016/S0032-9592(99)00050-3

Romaní, A., Garrote, G., López, F., \& Parajó, J. C. (2011). Eucalyptus globulus wood fractionation by autohydrolysis and organosolv delignification. Bioresource Technology, 102(10), 5896-5904. https://doi.org/10.1016/j.biortech.2011.02.070

Siqueira, G., Milagres, A. M. F., Carvalho, W., Koch, G., \& Ferraz, A. (2011). Topochemical distribution of lignin and hydroxycinnamic acids in sugar-cane cell walls and its correlation with the enzymatic hydrolysis of polysaccharides. Biotechnology for Biofuels, 4. https://doi.org/10.1186/1754-6834-4-7

Siqueira, G., Várnai, A., Ferraz, A., \& Milagres, A. M. F. (2013). Enhancement of cellulose hydrolysis in sugarcane bagasse by the selective removal of lignin with sodium chlorite, 102, 399-402. https://doi.org/10.1016/j.apenergy.2012.07.029

Sluiter, A., Hames, B., Ruiz, R., Scarlata, C., Sluiter, J., Templeton, D., \& Nrel, D. C. (2011). Determination of Structural Carbohydrates and Lignin in Biomass Determination of Structural Carbohydrates and Lignin in Biomass, 2011(April 2008).

Studer, M. H., DeMartini, J. D., Davis, M. F., Sykes, R. W., Davison, B., Keller, M., ... Wyman, C. E. (2011). Lignin content in natural Populus variants affects sugar release. Proceedings of the National Academy of Sciences, 108(15), 6300-6305. https://doi.org/10.1073/pnas.1009252108

Timell, T. E. (1961). Isolation of galactoglucomannans from the wood of gymnosperms. Tappi 44, (44), 88-96.

Wise, L. E., Maxine, M., \& D'Addieco, A. A. (1946). Chlorite holocellulose, its fractionation and bearing on summative wood analysis and on studies on the hemicelluloses. Technical Association of Pulp and Paper Industry, 29, 210-218.

Yu, H., Liu, R., Shen, D., Jiang, Y., \& Huang, Y. (2005). Study on morphology and orientation of cellulose in the vascular bundle of wheat straw. Polymer, 46(15), 5689-5694. https://doi.org/10.1016/j.polymer.2005.05.052 